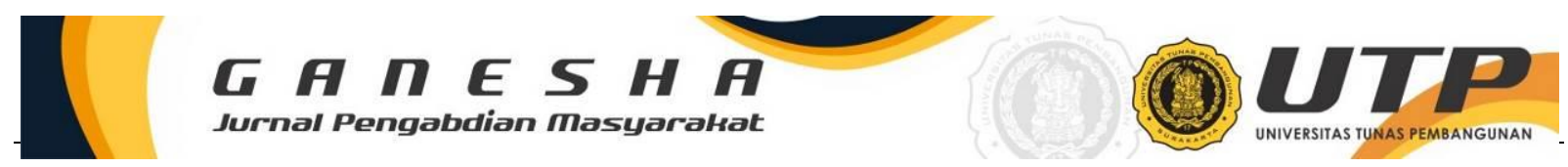

\title{
GERMAS (GERAKAN MASYARAKAT HIDUP SEHAT) SEBAGAI PENUNJANG PEREKONOMIAN UMKM DITENGAH PANDEMI COVID-19 DI JATEN KARANGANYAR
}

\author{
Zandra Dwanita Widodo ${ }^{1}$, Sri Wijiastuti ${ }^{2}$, Kurniawati Darmaningrum ${ }^{3}$ \\ Universitas Tunas Pembangunan Surakarta \\ Email Korespondensi: zandra.febutp@gmail.com ${ }^{1}$
}

\begin{abstract}
Abstrak
Pandemi Covid-19 menuntut perhatian berbagai pihak dalam upaya penanganan dan pencegahan penyebarannya. Berbagai macam program dan kebijakan dilakukan pemerintah untuk menangani hal tersebut. Namun, perkembangan kasus Covid-19 belum menunjukkan penurunan baik secara nasional maupun di Jaten Karanganyar menuntut peran aktif seluruh lapisan masyarakat maupun akademisi dalam upaya mencegah penyebarannya. Pandemi Covid-19 membuat semua penduduk terkhusus pelaku UMKM di wilayah Jaten Karanganyar menjaga kesehatan, menjaga perilaku hidup bersih dan sehat (PHBS). Bagian dari kegiatan Gerakan Masyarakat Hidup Sehat (GERMAS) dikala Covid-19 melanda diantaranya adalah cuci tangan, menjaga jarakmemakai masker, menjaga kebersihan lingkungan, berolahraga, dsb. Kegiatan pengabdian masyarakat dilaksanakan di Desa Jaten Kecamatan Jaten Kabupaten Karanganyar Provinsi Jawa Tengah terkhusus pelaku UMKM sebagai bentuk kepedulian dan dukungan kesehatan untuk menggerakan perekonomian masyarakat. Kegiatan yang dilakukan dalam upaya mencegah penyebaran virus corona adalah edukasi Covid19, pemberian e-book pedoman RT/RW pencegahan Covid-19 di grup RT dan RW, pembagian brosur, pemberian masker, penyemprotan disinfektan serta menggelorakan untuk terus menjaga kesehatan dengan berolahraga. Melalui sosialisasi dan edukasi, warga lebih memahami terkait dari pemahaman konsep, tanda atau gejala inveksi virus, tindakan pencegahan yang dilakukan jika terdapat anggota keluarga yang menunjukkan gejala Covid-9. Melalui pedoman dan brosur yang diberikan warga juga dianggap efektif dalam pemahaman dan aplikasi pencegahan dan penanganan. Selanjutnya pemberian masker sangat bermanfaat dalam mengurangi potensi penularan Covid-19. Pelaku UMKM di Jaten Karanganyar lebih waspada dan tenang dalam melakukan aktifitas perekonomian.
\end{abstract}

Kata kunci: germas, perekonomian, umkm, covid-19

\begin{abstract}
The Covid-19 pandemic demands the attention of various parties in efforts to handle and prevent its spread. Various kinds of programs and policies have been implemented by the government to deal with this issue. However, the development of the Covid-19 case has not shown a decline both nationally and in Jaten Karanganyar, demanding an active role from all levels of society and academics in an effort to prevent its spread. The Covid-19 pandemic has made all residents, especially SMEs in the Jaten Karanganyar area, maintain health, maintain a clean and healthy lifestyle. Part of the activities of the Healthy Living Community Movement (GERMAS) when Covid-19 hit included washing hands, maintaining distance, wearing masks, maintaining environmental hygiene, exercising, etc.Community service activities are carried out in Jaten Village, Jaten District, Karanganyar Regency, Central Java Province, especially SMEs players as a form of health care and support to drive the community's economy. Activities carried out in an effort to prevent the spread of the corona virus are Covid-19 education, provision of RT / RW guidelines for Covid-19 prevention in RT and RW groups, distribution of brochures, giving masks, spraying disinfectants and encouraging continuing to maintain health by exercising. Through socialization and education, residents have a better understanding of the concept, signs or symptoms of viral infection, and precautions to take if a family member shows symptoms of Covid-9. The guidelines and brochures provided by the residents were also considered effective in understanding and applying prevention and treatment. Furthermore, giving masks is very useful in reducing the potential for Covid-19 transmission. SMEs in Jaten Karanganyar are more alert and calm in carrying out economic activities.
\end{abstract}

Keywords: germas, economic, smes, covid-19 


\section{PENDAHULUAN}

Covid-19 merupakan infeksi virus yang sangat mudah menular yang disebabkan oleh sindrom pernafasan akut SARSCoV-2. Virus ini pertama kali muncul di Wuhan, Cina dan menyebar ke seluruh dunia diakhir tahun 2019. Analisis genom mengungkapkan bahwa SARSCoV-2 secara filogenetik masih berkaitan dengan virus kelelawar dengan ditandai sindrom pernapasan akut (seperti SARS) yang parah. Oleh karena itu kelelawar bisa menjadi reservoir primer yang memungkinkan. Sumber perantara asal dan transfer ke manusia tidak diketahui. Namun, cepat transfer manusia ke manusia telah dikonfirmasi secara luas (Shareen, et. al, 2020; Lupia, et. al, 2020).

Indonesia merupakan salah satu negara yang terkena dampak pandemi Covid-19. Berdasar data yang diperoleh dari Gugus Tugas Percepatan Penanganan COVID-19 menunjukkan bahwa perkembangan kasus COVID-19 di Indonesia cenderung mengalami peningkatan yang signifikan. Akumulasi data nasional per 13 Desember 2020 menunjukkan bahwa terdapat sejumlah 611.631 kasus terkonfirmasi. Data tersebut terdiri atas 34.668 dalam perawatan/isolasi mandiri, 501.376 sembuh dan 18.563 meninggal. (https://covid19.go.id/).

Fenomena pandemi Covid-19 ini berdampak pada seluruh sektor, terkhusus sektor ekonomi pada UMKM. Kajian yang dibuat oleh Kementerian Keuangan Republik Indonesia menunjukkan bahwa pandemi COVID-19 memberikan implikasi negatif bagi perekonomian domestik seperti penurunan konsumsi dan daya beli masyarakat, penurunan kinerja perusahaan, ancaman pada sektor perbankan dan keuangan, serta eksistensi UMKM (Kementerian Keuangan Republik Indonesia, 2020). Menurut data Rilis Badan Pusat Statistik (BPS) tentang pertumbuhan ekonomi triwulan II-2020, terjadi penurunan ekonomi nasional menjadi -5,32\% (Badan Pusat Statistik, 2020). Dan menurut Menteri Koperasi dan UMKM Teten Masduki berdasarkan hasil survei yang dilakukan sejumlah lembaga dan Kementerian Koperasi dan UKM (Kemenkop UKM), wabah COVID-19 memberikan dampak besar terhadap keberlangsungan UMKM. Sebanyak 1.785 koperasi dan 163.713 pelaku usaha mikro kecil menengah terdampak pandemi virus Corona, (Rani Ummi Fadila, 2020).

Hal ini menjadi perhatian kami para akademisi untuk berkontribusi langsung pada masyarakat pelaku UMKM yang terdampak akibat pandemik ini melalui kegiatan Tridarma Perguruan Tinggi dengan bentuk kepedulian dan dukungan kesehatan berupa konsep kegiatan GERMAS (Gerakan Masyarakat Hidup Sehat). Kegiatan Tridarma Perguruan tinggi salah satunya adalah pengabdian kepada masyarakat, merupakan kegiatan yang wajib dilaksanakan oleh dosen. Pelaksanaan pengabdian masyarakat program studi manajemen Faklutas Ekonomi Bisnis Universitas Tunas Pembangunan Surakarta memilih tempat di RT2 RW 19 Jaten, Kabupaten Karanganyar Provinsi Jawa Tengah. RT2/RW19 termasuk Kecamatan Jaten Kelurahan Jaten, terletak di Jl. Pusponyidro.

\section{METODE}

Kegiatan Pengabdian kepada Masyarakat ini dilaksanakan di RT 02 RW19 Kelurahan Jaten Kecamatan Jaten Kabupaten Karanganyar Provinsi Jawa Tengah. Kegiatan ini dilaksanakan dari tanggal 13 sampai 15 Desember 2020. Metode kegiatan dalam upaya pencegahan penyebaran Covid-19 dilakukan melalui:

a. Edukasi Covid-19

Edukasi Covid-19 kepada warga dimaksudkan untuk memberikan informasi secara langsung terkait bahaya Covid-19, mekanisme penularan dan penanganan. Dan juga pencegahan dengan GERMAS (Gerakan Masyarakat Hidup Sehat) melalui Group WA ( Dikarenakan kondisi tidak memungkinkan untuk berkegiatan massal). Memberikan semangat dan motivasi untuk terus bekerja, berkarya dan berusaha dalam membangun UMKM ditengah pandemi Covid-19. 
b. Penyemprotan Disinfektan

Kegiatan ini bertujuan untuk mendukung warga pelaku UMKM dalam mencegah penyebaran Covid-19 agar senantiasa menjaga kebersihan dan kesehatan lingkungan sekitar baik dirumah maupun tempat berdagang.

c. Pemberian Masker dan Brosur

Pemberian masker diharapkan dapat mengurangi penyebaran Covid-19, dan pemberian brosur untuk lebih memudahkan dalam menyampaikan pesan kepada warga agar tidak khawatir secara berlebihan, paham akan penanganan mandiri mengenai Covid-19 dan terus semangat bekerja untuk memajukan UMKM

d. Bersolahraga Bersama Warga Pelaku UMKM

Berkontribusi langsung melalui kegiatan olahraga bersepeda yang merupakan salah satu unsur GERMAS. Kegiatan ini bertujuan untuk menjaga api semangat para pelaku UMKM untuk tetap semangat dan optimis menjalani hidup ditengah pandemi Covid19.

\section{HASIL DAN PEMBAHASAN}

Kegiatan pengabdian kepada masyarakat dilaksanakan selama 3 hari yakni sejak tanggal 12-16 Desember 2020 di J1.Pusponyidro no 18 RT2/RW19 Desa Jaten Kecamatan Jaten Kabupaten Karanganyar Provinsi Jawa Tengah.

\section{a. Edukasi Covid-19}

Edukasi Covid-19 kepada warga dimaksudkan untuk memberikan informasi secara langsung terkait bahaya Covid-19, mekanisme penularan dan penanganan. Dan juga pencegahan dengan GERMAS (Gerakan Masyarakat Hidup Sehat) melalui Group WA ( Dikarenakan kondisi tidak memungkinkan untuk berkegiatan massal). Memberikan semangat dan motivasi untuk terus bekerja, berkarya dan berusaha dalam membangun UMKM ditengah pandemi Covid-19.

Pelaksanaan teknis dilakukan dengan ijin terlebih dahulu dengan Ketua RT dan juga ibu ibu DAWIS RT02/19 Desa Jaten Kecamatan Jaten Kabupaten Karanganyar. Berkaitan dengan himbauan pemerintah daerah untuk tidak melakukan kegiatan massal terlebih dahulu, dan menhindari kerumunan selama masa pandemic Covid-19. Kegiatan ini dilakukan melalui diskusi via group WA yang beranggotakan ibu ibu DAWIS yang termasuk dalam pelaku UMKM, menginformasikan dan mensosialisasikan GERMAS untuk pencegahan penuluran Covid-19. Memberikan informasi gratis berupa buku pedoman Covid-19 untuk RT dan RW.Lihat gambar 1 .

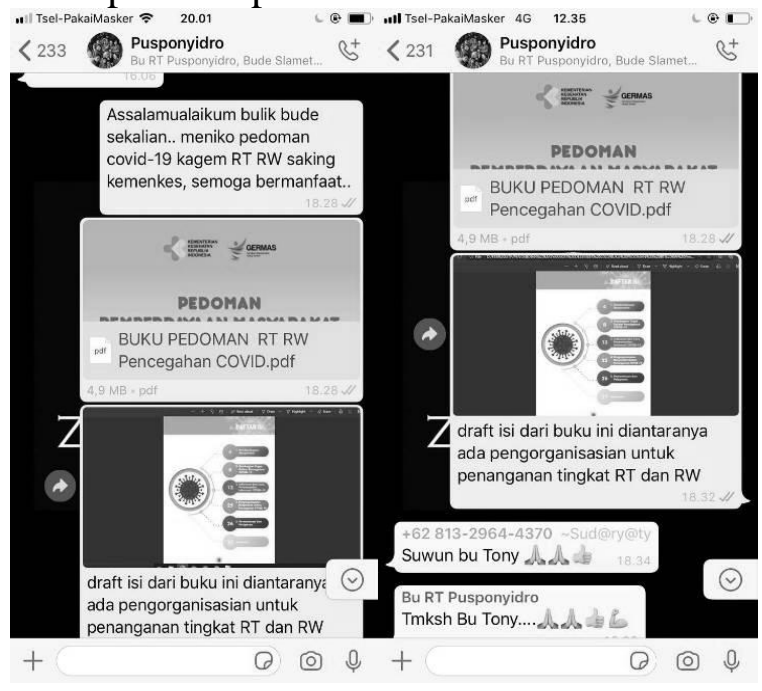

Gambar 1. Edukasi Covid-19 by WA 


\section{b. Penyemprotan Disinfektan}

Kegiatan ini bertujuan untuk mendukung warga pelaku UMKM dalam mencegah penyebaran Covid-19 agar senantiasa menjaga kebersihan dan kesehatan lingkungan sekitar baik dirumah maupun tempat berdagang. Teknis pelaksanaan kegiatan ini adalah berkoordinasi dengan ketua RT untuk kerja bakti di hari sabtu, dikarenakan penyemprotan dilakukan dijam produktif sehingga warga yang hadir untuk berkontribusi langsung kerja bakti sedikit.

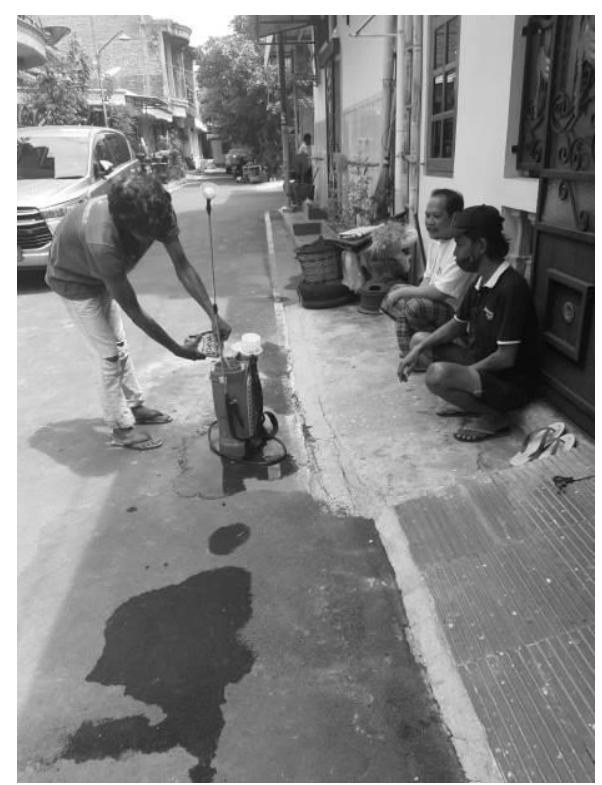

Gambar 2. Penyemprotan Disinfektan

\section{c. Pemberian Masker dan Brosur}

Pemberian masker diharapkan dapat mengurangi penyebaran Covid-19, dan pemberian brosur untuk lebih memudahkan dalam menyampaikan pesan kepada warga agar tidak khawatir secara berlebihan, paham akan penanganan mandiri mengenai Covid-19 dan terus semangat bekerja untuk memajukan UMKM

Brosur menjadi alternatif media untuk memberikan informasi. Selain berdiskusi dan memberikan edukasi, tim pengabdian kepada masyarakat juga memberikan yang berbentuk selembaran kertas yang berisi informasi tentang Covid19 dan ditambah gambar pendukung yang diselipkan pada plastik pembungkus masker. Konten dari brosur tersebut memuat ajakan untuk selalu mawas diri terhadap kesehatan, menghimbau untuk senantiasa menjaga kesehatan dan berkontribusi dalam pencegahan Covid-19 dan terus berinvoasi bekerja dalam memajukan perekonomian.

Masker menjadi hal penting bagi setiap orang ditengah pandemic Covid-19 ini. Pemerintah menghimbau untuk seluruh warga menggunakan masker Ketika beraktifitas diluar rumah, agar tidak saling menulari.

Teknis pelaksanaan dari kegiatan ini adalah door to door membagikan masker berserta brosur kepada warga pelaku UMKM. 


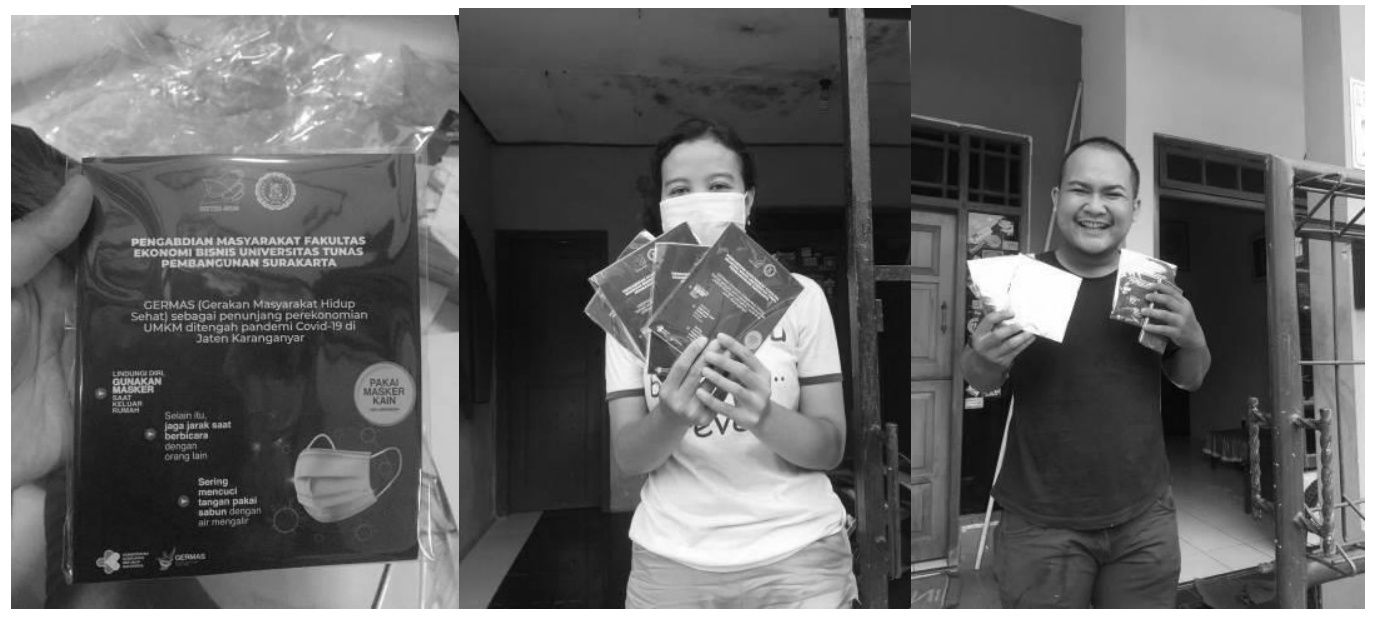

Gambar 3. Pemberian Masker dan Brosur

\section{d. Bersolahraga Bersama Warga Pelaku UMKM}

Berkontribusi langsung melalui kegiatan olahraga bersepeda yang merupakan salah satu unsur GERMAS. Kegiatan ini bertujuan untuk menjaga api semangat para pelaku UMKM untuk tetap semangat dan optimis menjalani hidup ditengah pandemi Covid-19. Teknis pelaksanaan kegiatan ini adalah dengan berkoordinasi langsung dengan ketua paguyuban olahraga sepeda di lingkungan RT.

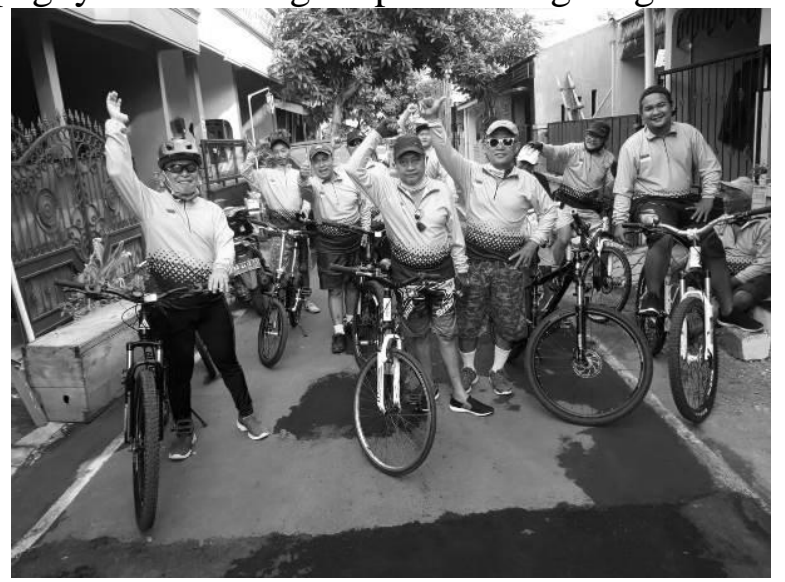

Gambar 4. Berolahraga Bersama warga Pelaku UMKM

\section{KESIMPULAN}

Kegiatan pengabdian kepada masyarakat yang dilaksanakan selama 3 hari yakni sejak tanggal 12-16 Desember 2020 berjalan dengan baik lancar. Edukasi Covid-19 kepada warga pelaku UMKM melalui grup WA dengan memberikan e book gratis mengenai Covid-19 dan GERMAS dalam rangka membantu warga dalam memahami baik dari pemahaman konsep, tanda atau gejala inveksi virus, tindakan pencegahan yang dilakukan jika terdapat anggota keluarga yang menunjukkan gejala covid-19. Penyemprotan disinfektan bertujuan untuk mendukung warga pelaku UMKM dalam mencegah penyebaran Covid-19 agar senantiasa menjaga kebersihan dan kesehatan lingkungan sekitar baik dirumah maupun tempat berdagang. Pemberian masker diharapkan dapat mengurangi penyebaran Covid-19, dan pemberian brosur untuk lebih memudahkan dalam menyampaikan pesan kepada warga agar tidak khawatir secara berlebihan, paham akan penanganan mandiri mengenai Covid-19 dan terus semangat bekerja untuk memajukan UMKM. Berkontribusi langsung melalui kegiatan olahraga bersepeda yang merupakan salah satu unsur GERMAS. Kegiatan ini bertujuan untuk menjaga api semangat para pelaku UMKM untuk tetap semangat dan optimis menjalani 
hidup ditengah pandemi Covid-19. Kegiatan pengbdian kepada masyarakat ini diharapkan dapat mendorong seluruh masyarakat Indonesia mamahami dan melaksanakan GERMAS dalam menjalani kehidupan sehari-hari, dengan harapan angka pasien Covid-19 menurun.

\section{UCAPAN TERIMA KASIH}

Kami sebagai team pengabdian mengahturkan terimakasih untuk Bapak Ibu Pimpinan Dekanat dan Prodi Manajemen Fakultas Ekonomi Bisnis Universitas Tunas Pembangunan Surakarta yang telah mendukung kami para akademisi untuk menyelesaikan tugas Tridarma Perguruan Tinggi. Kami juga mengucapkan terima kasih kepada Ketua RT, ibu ibu serta warga Jl.Pusponyidro No.18 RT2/RW19 Desa Jaten Kecamatan Jaten Kabupaten Karanganyar yang telah memberikan dukungan dan sambutan yang begitu hangat dalam proses kegiatan pengabdian masyarakat kami. Semoga kita semua diberikan perlindungan kesehatan dan keselamatan ditengah pandemi Covid-19 ini.

\section{DAFTAR PUSTAKA}

Shereen, Muhammad Adnan., Khan, Suliman., Kazmi, Abeer., Bashir, Nadia., and Siddique, Rabeea. (2020). COVID-19 Infection: Origin, Transmission, and Characteristics of Human Coronaviruses. Jurnal of Advanced Research. 24(2020), 91 98.

Gugus Tugas Percepatan Penanganan COVID-19. (2020). Peta Sebaran. https://covid19.go.id/peta-sebaran. Diakses Tanggal 12 Desember 2020

Badan Pusat Statistik. (2020). Ekonomi Indonesia Triwulan II 2020 Turun 5,32 Persen. Retrieved from https://www.bps.go.id/website/materi_i nd/materiBrsInd20200805114633.pdf

Kementerian Keuangan Republik Indonesia. (2020). Press Conference; Langkah Penguatan Perlindungan Sosial Dan Stimulus Ekonomi Menghadapi Dampak Covid-19. Retrieved from https://www.kemenkeu.go.id/media/14 790/materi-konferensi-pers-1april2020.pdf

Rani Ummi Fadila. (2020). 1.785 Koperasi dan 163.713 UMKM Terdampak Pandemi Covid-19. Retrieved from https://www.pikiranrakyat.com/ekonomi/pr01379615/1785koperasi-dan-163713- umkm-terdampak-pandemi-covid-19 